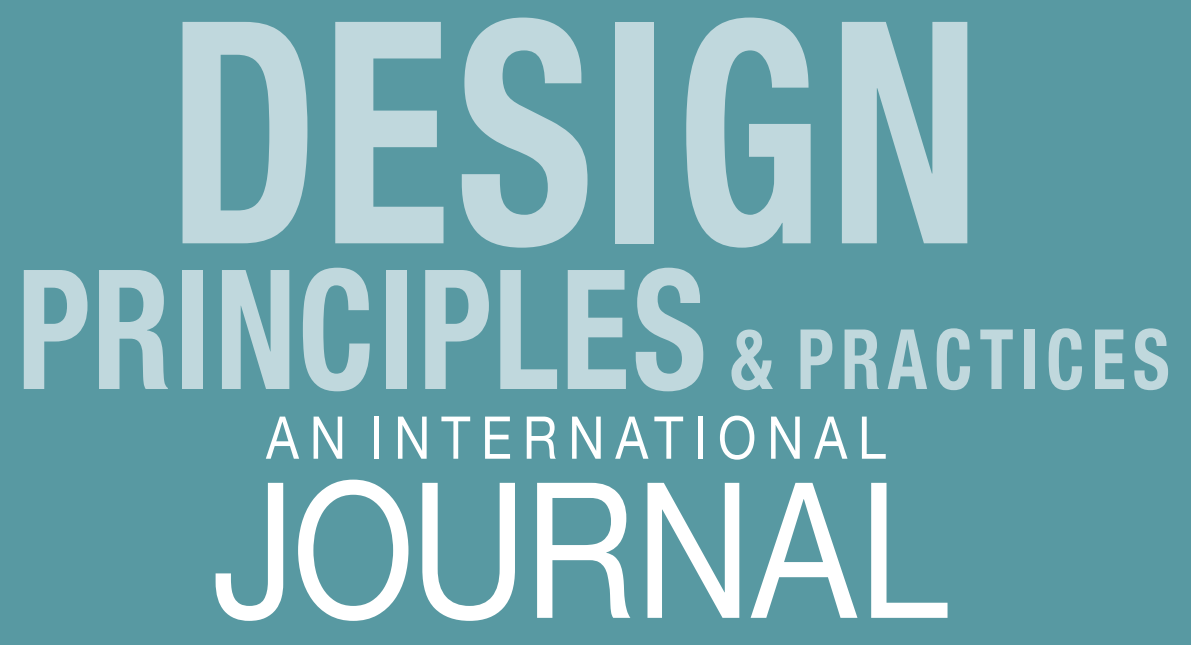

Volume 5, Number 4

Architectural Design Principles and Processes for Sustainability: Towards a Typology of Sustainable Building Design

David Grierson and Carolyn Moultrie 
DESIGN PRINCIPLES AND PRACTICES: AN INTERNATIONAL JOURNAL http://www.Design-Journal.com

First published in 2011 in Champaign, Illinois, USA

by Common Ground Publishing LLC

www.CommonGroundPublishing.com

ISSN: $1833-1874$

(C) 2011 (individual papers), the author(s)

(c) 2011 (selection and editorial matter) Common Ground

All rights reserved. Apart from fair dealing for the purposes of study, research, criticism or review as permitted under the applicable copyright legislation, no part of this work may be reproduced by any process without written permission from the publisher. For permissions and other inquiries, please contact

<cg-support@commongroundpublishing.com>.

DESIGN PRINCIPLES AND PRACTICES: AN INTERNATIONAL JOURNAL is peerreviewed, supported by rigorous processes of criterion-referenced article ranking and qualitative commentary, ensuring that only intellectual work of the greatest substance and highest significance is published.

Typeset in Common Ground Markup Language using CGPublisher multichannel typesetting system

http://www.commongroundpublishing.com/software/ 


\title{
Architectural Design Principles and Processes for Sustainability: Towards a Typology of Sustainable Building Design
}

\author{
David Grierson, University of Strathclyde, Scotland, UK \\ Carolyn Moultrie, University of Strathclyde, Scotland, UK
}

\begin{abstract}
The paradigm shift for sustainable buildings requires a transformation of the architectural design process. This paper examines how sustainability is embedded into design methodology and mapped onto, or has transformed, the design process. Interviews with a sample of Scottish architectural and multi-disciplinary practices were undertaken to explore the common approaches and barriers to sustainable design. Case study methodology was also employed to consider exemplar buildings and the value of post-occupancy evaluation is discussed. Within the context of the global environmental perspective, UK and Scottish legislation, sustainable principles and blueprints, a process model is developed to provide a framework for discussion and review. The first creative step is given as an alignment of practice ethos with established architectural philosophies and principles, from across the sustainability spectrum, to move towards a typology of sustainable building design.
\end{abstract}

Keywords: Sustainable Design, Processes and Principles, Scottish Architectural, Multi-disciplinary Practices

\section{Introduction}

$\mathrm{B}$

UILDINGS CONSUME ENERGY and resources and generate waste on a huge scale. Current construction methods tie us into future patterns of resource and energy use, waste emissions and environmental damage. When poorly designed our buildings leave a lasting legacy for the next generation that extends adverse social, economic and environmental impacts throughout their life cycle. The Scottish Executive's A Policy for Architecture in Scotland acknowledges that the complex and challenging sustainability agenda requires fundamental change in our understanding of the nature and purpose of buildings and the role of building design (Scottish Executive, 2006).

There are many definitions of what makes a building sustainable with respect to social, economic and environmental issues (commonly referred to as the 'triple bottom line'); social in terms of adding to the quality of life for people, economic in terms of enhancing wealth, and environmental in terms of reducing the impact that buildings have on the natural environment. However the 'triple bottom line' of sustainability is open-ended and ecological aspirations vary widely, more recently focussing on aspects relating to transport, water conservation, and biodiversity. A current significant focus is being placed on the energy and environmental performance of buildings, with specific key goals involving the reduction of associated carbon emissions and energy costs. Identifying and developing more sustainable building materials and construction techniques that can minimize waste and are non-polluting is recognised as an important aspect of sustainable building design. 
Sustainable buildings must be resilient to climate change and be adaptable, flexible and durable in order to increase a building's life-span. This 'cradle to cradle' approach refers to a building that is designed to be deconstructed and where materials are capable of being recycled. Design parameters for sustainable buildings have therefore increased to encompass more complex performance related criteria, and the architect must adopt a more holistic perspective when designing. Sustainable buildings remain, however, far from the mainstream products. Indeed there are a limited number of contemporary exemplars and demonstration projects from which to learn good practice, although this number has expanded in recent years. The construction industry can be viewed as large and fragmented and slow to respond to change, preferring the 'tried and tested method'. The drivers to a more sustainable built environment will be increasing legislation and rising energy costs, if not ethics.

The architect's role is central to the building design process: the most energy efficient and environmentally friendly building must also be functional, durable and aesthetically pleasing. It is now vital that the architect has a comprehensive understanding of all the facets of sustainability in order to be able to engage with a wide range of disciplines and specialisms.

The underlying hypothesis of the research is that a shift towards sustainable buildings requires a transformation of the architectural design process and the development of a new framework to navigate the complexities of sustainable design within a context that is promoting step change in building performance globally. The articulation of a framework that can be responsive to this context will involve the identification of approaches to sustainable building design being adopted within current architectural practice, and the emergence of a related typology.

\section{Towards a Typology}

Research into the implementation of environmental management systems (International Organisation for Standardisation, 1996) within the wider context of sustainable development has raised issues of fundamental importance to the understanding of the concept if appropriate action is to be taken. In particular, consideration has been given as to how a practical realisation of such a system might be applied to the lifecycle of a building, including the design phase (Grierson, 2009). We need visions of a more sustainable future that can provide the current generation of designers and planners with sufficient motivation without impairing their capacity to learn what might be the best direction for change. At the same time we urgently need to improve the energy and environmental performance of the global built environment. An improved building design process aided by appropriate management tools and regulatory frameworks that address sustainable development issues has been suggested as a way forward, and is the subject of ongoing research (Grierson, 2009). The objectives of this part of the research are to investigate the design principles and processes for sustainability and to explore them in action within current practice. A study, which aimed to gain the practitioner's perspective, was undertaken as dissertation work within the Masters of Research programme in Building Design and Management at the Department of Architecture, University of Strathclyde Glasgow during 2010 (Moultrie, 2010). This was achieved by engaging with a small sample of Scottish architectural and multi-disciplinary practices actively involved in sustainable design and by considering exemplar buildings via a case study analysis. The methodology was qualitative, involving face to face interviews and observational visits to the case study buildings. A context was established by reviewing literature focusing on the 
global environmental perspective, UK and Scottish legislation, sustainable principles, blueprints, sustainable processes and evaluation. Analysis of the practitioner and client interviews, in combination with the case studies, allowed for discussion and response to a number of research questions. To conclude the study a series of mapping exercises were carried out to allow for comparison and cross-referencing. An example within the paper describes the 'Principles Matrix' which shows the overlapping principles from selected literature (Table 1). Key components of a sustainable design process are identified as the environmental brief, parameters, environmental strategies, evaluation and tools and techniques. These components were used in the analysis of exemplar case studies from practices. Table 2 maps the sustainable process onto the Royal Institute of British Architects (RIBA) Outline Plan of Work. An example of a case study building summary table, indicating relevant processes and applicable principles is given in Table 3.

\section{Context}

Sustainable development was described in the 1987 Bruntland Commission's report (WCED, 1987) as, "development that meets the needs of the present without compromising the ability of future generations to meet their own needs." In achieving social and economic goals the commission recognised that ecosystems must be safeguarded and the depletion of natural resources minimized. At the same time investing in skills and the advancement of knowledge for the benefit of future generations must be prioritised.

The European Union Energy Performance of Buildings Directive was published on the 4th January 2003 (EU, 2003). The overall objective of the Directive is to promote the improvement of energy performance of buildings within the Community taking into account outdoor climatic and local conditions, as well as indoor climate requirements and cost-effectiveness. Each EU member state was required to transpose the Directive into law by the beginning of 2006 with a further three years being allowed for full implementation of specific articles.

The UK Climate Change Bill (2007) set challenging targets for carbon reductions across the UK with a commitment to a $50 \%$ cut in carbon emissions from the built environment by 2020. Under the EU commitment the UK must deliver 15\% of total energy from renewable sources. The zero carbon new building programme is seen as an active driver towards the renewable target. The UK policy is for all new homes to be zero carbon by 2016 , all new schools zero carbon by 2016, public sector buildings by 2018 and potentially all new buildings by 2019. In August 2007, the Scottish Government appointed a panel of experts to make recommendations to improve the performance of buildings. The outcome was A Low Carbon Building Standards Strategy for Scotland, widely known as The Sullivan Report (Sullivan, 2007). The intention of the report is to drive a step change in legislation, design and construction practice with the aspiration to move to total life zero carbon buildings by 2030. Legislation and policies may be drivers for sustainable buildings. However the level of 'greenness' of a building often depends on client aspirations and the approach taken by the architect and the design team. 


\section{Sustainable Principles \& Processes}

The aim of the research has been to examine the architectural design principles and processes that underpin sustainable building design as an emerging typology as described in selected key texts that can help identify a spectrum of approaches to sustainable design, and a series of related but distinct principles involving social, environmental, and economic factors.

In Ecological Design (1996) Van der Ryn and Cowan set out 5 principles formulated from their many years of research and practice. In their view the transformation to a more sustainable world encompasses a renewed approach to the design of buildings and products and will incorporate an understanding of ecological principles. The application of these principles involves an engagement or integration and sharing of knowledge across many sectors.

The concept of an individual dwelling that can be self-sufficient with regard to its own energy and resource needs, by for example harvesting rain and recycling waste, was described in the seminal book The Autonomous House (Vale and Vale, 1975). Some years later, in Green Architecture (1991) the authors described 6 principles as a basis for the 'green' design process. The Hockerton Housing project was designed by the Vales following these defined principles and is intended to be self-sufficient. The earth-sheltered terrace of five dwellings was built by residents and completed in 1998. A south facing glazed conservatory provides a passive solar heating source to the house, and surrounding land is used for growing crops and keeping small animals. The development is described as one of the first "zero energy" residential schemes in the UK (Hockerton Housing project, 2010).

The changing climate and the importance of designing resilient buildings that mitigate damage to the environment and that are capable of adaptation, leads to a crisis planning scenario in Adapting Buildings and Cities for Climate Change a $21^{\text {st }}$ century survival guide (Roaf, 2004). The author of the book describes the need for buildings to be resilient to climate change and be designed for longevity with low embodied energy.

An holistic approach to sustainability reaches beyond buildings to encompass sustainable communities and lifestyles. The environmental group BioRegional and the World Wildlife Fund (WWF) have developed the One Planet principles to enable sustainability to be embedded into any process. One Brighton (2005), designed by the architect Fielden Clegg Bradley Studios, is a mixed use residential development, funded by a mainstream developer Crest Nicholson along with BioRegional. It is the first development to use the One Planet principles and is aiming to be both 'zero carbon' and 'zero waste'. The linear blocks comprise 172 residential units above community and business units. An on-site car club, community centre, crèche and café is shared by all. There are mini allotments within the sky-gardens and terraces to encourage residents to grow food on site (Clegg, 2007). As a summary a Principles Matrix (Table 1) was produced to show the alignment of principles reviewed. The matrix indicates that a core set of principles align across all four sets. Additionally, the One Planet Principles outlines social / economic principles that are applicable to resident lifestyle choices, for example, with respect to food and fair-trade. 
Table 1: Principles Matrix

\begin{tabular}{|c|c|c|c|c|}
\hline Principles & Ecological Design & Green Architecture & One Planet & $\begin{array}{l}\text { Adapting Buildings for Climate } \\
\text { Change }\end{array}$ \\
\hline Authors & S.Van der Ryn, S.Cowan & B.Vale, R.Vale & BR, WWF & S.Roaf \\
\hline Environmental & -making nature visible & -holism & $\begin{array}{l}\text {-natural habilats and } \\
\text { wildlife }\end{array}$ & $\begin{array}{l}\text {-not destroy fragile biodivarsity and } \\
\text { ecosystems }\end{array}$ \\
\hline Environmental & -design with nature & $\begin{array}{l}\text {-conserving energy } \\
\text {-working with climate }\end{array}$ & -zero carbon & $\begin{array}{l}\text {-use as little energy as possible } \\
\text { through good design } \\
\text {-provide that energy, where pos sible } \\
\text { from clean, renewable sources that } \\
\text { will not pollute nor run out }\end{array}$ \\
\hline Environmental & -ecological accounting & $\begin{array}{l}\text { minimizing new } \\
\text { resources }\end{array}$ & $\begin{array}{l}\text { local and sustainable } \\
\text { malerials } \\
\text {-sustainable transport } \\
\text {-sustainable water } \\
\text {-zero waste }\end{array}$ & $\begin{array}{l}\text {-reduce waste in construction, } \\
\text { operation and demolition }\end{array}$ \\
\hline Social & -everyone is a designer & -respect for users & -health and happiness & $\begin{array}{l}\text {-promote the health of all } \\
\text { ensure that people are confortable } \\
\text { and can survive even in extreme } \\
\text { weather within them } \\
\text {-be built with goods and materials } \\
\text { that produce minimal pollution }\end{array}$ \\
\hline Economic & -solutions grow from place & -respect for site & -culture and heritage & \\
\hline Economic & & & equity and fairtrade & \\
\hline Economic & & & -local and sustainable food & \\
\hline
\end{tabular}

The transformation of design and construction process towards more sustainable practices will be supported by the identification of a classification system that can clarify issues at various stages of the process. In the UK, The Outline Plan of Work (RIBA, 2007) is a framework devised by the Royal Institute of Architects to structure these design and construction processes. It is widely used by architects and clients today as a management tool. The design and construction sequence, from appraisal to post practical completion, is broken down into a series of stages that can be arranged to suit different procurement methodologies. The phases involve a common set of tasks with outcomes related to the stages of pre-design; concept design; schematic design; detail design; post-occupancy evaluation.

Kwok (2007) aims to set out strategies at the schematic stage in The Green Studio Handbook. The sustainable design strategies are form giving and therefore influence the building design concept. Given that green buildings are an important step on the path to a more sustainable society Hyde (2007) attempts to set out a systematic design delivery design process in The Environmental Brief, Pathways for Green Design. The author argues that clients, designers and contractors are more interested in sustainable building design as knowledge increases of the benefits and the processes to deliver are better understood. The environmental brief encapsulates economic, social and environmental issues and is continuous throughout the design process. The environmental briefing system encompasses the following:

- Aspirations: sustainable principles, outline brief

- Divergence: establishing environmental objectives, functional requirements

- Parameters: site and climate, environmental criteria, whole life costing, legislation 
- Environmental Strategies: resource producing, passive/ active systems design, material specification, healthy environment, etc

- Applications: design testing

- Outcome: project brief

It is recognized that environmental briefing is a continuous process, responding to detail decision and value engineering throughout the design process. The system is viewed as a way of mapping sustainability onto the traditional design process. A process model has been developed from the literature reviewed and is here used for the case study format. The Sustainable Design Process Matrix (Table 2) maps the principles, environmental brief, parameters, environmental strategies, evaluation, tools and techniques onto the RIBA Outline Plan of Work. It indicates a spread from setting sustainable principles at the outset (Stage A) to postoccupancy evaluation of a building in use (Stage L).

Table 2: Sustainable Design Process Matrix

\begin{tabular}{|l|c|c|c|c|c|}
\hline $\begin{array}{l}\text { Outline Plan } \\
\text { of work }\end{array}$ & $\begin{array}{l}\text { Sustainable } \\
\text { Principles }\end{array}$ & $\begin{array}{l}\text { The } \\
\text { Environmental } \\
\text { Brief }\end{array}$ & $\begin{array}{l}\text { Parameters } \\
\text { Strategies }\end{array}$ & $\begin{array}{l}\text { Tools \& } \\
\text { Techniques }\end{array}$ \\
\hline A Appraisal & $\checkmark$ & $\checkmark$ & $\checkmark$ & $\checkmark$ & $\checkmark$ \\
\hline B Brief & & $\checkmark$ & $\checkmark$ & $\checkmark$ & $\checkmark$ \\
\hline C Concept & $\checkmark$ & $\checkmark$ & $\checkmark$ & $\checkmark$ \\
\hline $\begin{array}{l}\text { D Design } \\
\text { Development }\end{array}$ & $\checkmark$ & & $\checkmark$ & $\checkmark$ \\
\hline $\begin{array}{l}\text { E Detail } \\
\text { Design }\end{array}$ & & & & $\checkmark$ & $\checkmark$ \\
\hline $\begin{array}{l}\text { F Production } \\
\text { ITender }\end{array}$ & & & & $\checkmark$ & $\checkmark$ \\
\hline $\begin{array}{l}\text { J/K } \\
\text { Construction }\end{array}$ & & & & & $\checkmark$ \\
\hline L Occupancy & & & & $\checkmark$ \\
\hline
\end{tabular}

\section{Results and Analysis}

The adopted research method for the study was investigative, exploratory and descriptive. The five architectural and one multi-disciplinary practice that formed the research group range in size from small to large and operate across a variety of sectors. The larger practices have a sustainability team within the office that provides in-house support and external consultancy services.

A series of interviews were conducted with senior professionals of the practices and the case study client bodies. The face to face semi-structured interviews provided an overarching view of the practice ethos and the design process. The case study buildings from the practices are from social housing, education, commercial office and private developer housing sectors and are both new build and retrofit. To explore the design process in detail interviews were held with the project architect/ engineer. Visiting the buildings provided an opportunity to interview the client on site to gain their perspective and allow for a descriptive element of the final product - the building itself. The analysis and description framework for the case studies includes principles, environmental brief, parameters, evaluation and tools and techniques, identified following the literature review. 
Moving towards a typology of sustainable building design is a recent phenomenon for most architectural practices as the research has shown. All the research group practices have a sustainability policy in place. These policies describe a commitment to sustainable design as an integral part of their design philosophy. The general intent is that sustainability overarches the design process for every new project. The triple bottom line of sustainability 'social, economic and environmental' is a recognized mantra across all the research group practices. The divergence occurs in going beyond the triple bottom line and composing a set of principles. The research group was split between those having a set of principles in place and those currently developing principles. As every practice is unique, having developed a different architectural ethos, attempting to define where a practice sits on a 'sustainability spectrum' was seen as a useful starting point, from which a set of principles could then be developed to express their particular focus. An exercise was carried out to suggest alignments between the practice group and the philosophy and principles from key texts (Table 1).

One of the practices has been a pioneer in ecological design for a number of years and therefore could be said to align broadly with all the principles. Another of the practice has a strong social/ community ethos therefore the core principles of One Planet align well (Bioregional and WWF). Adapting Buildings for Climate Change (Roaf, 2004) involves the performance of buildings and is aimed at architects and engineers. The principles overlap with those of the global multi-disciplinary practice. A holistic approach and an emphasis on place making and people described by another of the practices fits well with the ideals of Green Architecture (Vale and Vale, 1975). In Ecological Design (1996) Van der Ryn and Cowan express a deep green philosophy and in Ecological Design Redux (2008) the authors examine how many of the principles have been embraced by others in the intervening period. Connections are, for example, made with the emerging practical application of the One Planet principles. Additionally within the research group the principles of 'ecological accounting', 'designing with nature', and the concept that 'everyone is a designer' are evident in one practice in particular which balances green ideals with a pragmatic approach, while engaging well with the end users. Creating intelligent buildings that exhibit low carbon footprints, while also being comfortable and attractive places for people to inhabit, was an aim of a larger practice which had an in house sustainability group. The developing ideals also mirror the ethos of the principles in Adapting Buildings for Climate Change where the value of the resilience of buildings is emphasised.

The practical application of the principles and process was evidenced through the case studies. These examined what principles (from Table 1) were directly applicable and summarised the key processes involved. One of these case studies - the refurbishment and extension of a modernist 1960's office building is given by way of illustration (Table 3). In this case, the office building was no longer seen as fit for purpose with an inflexible working environment and lack of space. In 2005, Historic Scotland listed the building as Grade B due to the modernist design. The environmental brief was to refurbish and extend the existing building to create a building that was energy efficient, low carbon and fit for new ways of office working while creating an attractive comfortable working environment. The redevelopment was to reflect the client's environmental ethos and act as a showcase of their work. The environmental strategies included passive design principles, intelligent active energy systems, component design, and sustainable material choice. A renewable energy source for the heating and hot water was provided by way of a biomass boiler. Working with the constraints of the existing building and surroundings set the design parameters. It was not 'sus- 
tainability at any cost': appropriate solutions for the scale of the project were identified to deliver best value. At the design stage the building has achieved an Energy Performance Certificate rating of A. A BREEAM 'excellent' rating was achieved and a post occupancy evaluation was undertaken as soon as the building was occupied, monitoring all energy use and the building systems in use.

Table 3: Case Study, Principles and Process Summary

\begin{tabular}{|l|l|}
\hline PRINCIPLES & PROCESS \\
\hline $\begin{array}{l}\text { Ecological Design } \\
\text { solutions grow from place } \\
\text { design with nature } \\
\text { ecological accounting } \\
\text { everyone is a designer }\end{array}$ & $\begin{array}{l}\text { Environmental Brief -carbon reduction, energy efficienct, } \\
\text { flexible working cnvironment }\end{array}$ \\
$\begin{array}{l}\text { Green Architecture } \\
\text { working with climate } \\
\text { conserving energy } \\
\text { respect for site } \\
\text { minimising new resources }\end{array}$ & Parameters - grade B listed building, budget \\
$\begin{array}{l}\text { One Planet } \\
\text { culture and heritage } \\
\text { sustainable water } \\
\text { natural habitats and wildlife } \\
\text { zero carbon }\end{array}$ & $\begin{array}{l}\text { ventilation and improved thermal performance. Renewable } \\
\text { energy source for heating, biomass boiler. Landscape work to } \\
\text { promote biodiversity }\end{array}$ \\
$\begin{array}{l}\text { Adapting Buildings for Climate Change } \\
\text { use as little energy as possible through good design } \\
\text { reduce waste in construction operation and demolition } \\
\text { ensure that people are comfortable \& can survive even in extreme weather within them }\end{array}$ & $\begin{array}{l}\text { Evaluation - BREEAM 'excellent'. Energy, water, CO2 } \\
\text { monitoring to be continually carried out }\end{array}$ \\
& Tools \& Techniques- environmental modelling \\
\hline
\end{tabular}

\section{Discussion}

Evidence of the demonstration of sustainable principles and processes within the case study buildings vary and can be attributed to many factors; the timeline of the buildings, the client's sustainability goals, the environmental brief and budget and the architect's creative response to the design intent and criteria. Buildings are often recognizable as belonging to a certain practice or architect through architectural style. Sustainable design is evidenced more within a philosophical approach that involves the application of principles at various stages of the design process. The research material gathered from the practice interviews, client interviews, and case studies indicates that, for example, aspects of passive design, sustainable material choice, and the use of new technologies are having an impact in driving the form and envelope of many of today's buildings.

Although the design processes within the research practice group are different key common elements are evident. The framework takes the new environmental brief as the starting point. The specific design criteria for the project are established and goals are set at the briefing stage. Parameters or filters are then applied which influence the environmental strategies. The environmental strategies are developed to meet the design intent. There are many sets 
of principles that cover the holistic sustainability spectrum although no one common set of metrics exists (Jencks, 1997). Principles have similar core elements and it could be assumed by now that all architects would accept that buildings should deliver value to the community, environment and the end user (Sassi, 2006). It is of value to have a set of principles in place for a number of reasons, not least because they offer a useful guide or checklist. At a higher level however principles can reflect the ethos of a practice - the practice view, for example, on community issues or ecological issues. The principles can therefore be used to articulate and explore client aims and sustainability goals in structured, possibly facilitated, conversations among key stakeholders.

Sustainable principles alone however do not set a project brief. The sustainable design process must include an analysis and synthesis of a whole new sub-set of social, environmental, and economic goals, with specific criteria set alongside functional requirements. As the case studies have indicated in the current study, clients often have specific sustainable design objectives and balancing them with functional goals has to be considered at the outset. These include those that relate to the site constraints which determine that each building, even repeat type standard buildings are unique because of their location. Each site exhibits different physical characteristics that have an effect on the building at least in terms of location, micro-climate, access and physical ground conditions. Within sustainable buildings the response to the site context is more acute and is one of the major determinants on the development of sustainable strategies involving a response to micro-climate, topography, adjoining neighbours, local community and local planning policies. These can be regarded as opportunities or constraints.

The study demonstrates that an integrated approach is needed from the outset to set sustainable strategies as early as possible. All practices stated the desire to avoid bolt on visible displays of 'green technology' such as solar panels or wind turbines (i.e. the 'eco-bling' factor). Rather the common approach adopted focused on passive design issues (i.e. site orientation, form, building envelope), combined with active design elements (i.e. intelligent service design to minimise energy consumption), and then finally to reduce carbon emissions further considered renewable energy sources. Common strategies adopted within the case studies within an integrated design process involved; lighting, heating, ventilation and cooling, energy production, water, materials, conservation, biodiversity and waste

\section{Evaluation Systems}

Post occupancy evaluation (POE) of sustainable buildings is important because it is only when a building is occupied that the design intent can be ultimately tested. The views of building users or occupiers can then provide valuable feedback on the design quality, functionality and comfort. Analysing energy and thermal performance in use against design intent benchmarks will help inform future design strategies. POE is particularly important for sustainable buildings in monitoring how the building performs in terms of energy use, $\mathrm{CO} 2$ emissions and water consumption. Sustainable buildings don't always perform as well as intended. This can be put down to a variety of factors including the use of new technology, control and monitoring systems and not least the human factor. Exemplar buildings and demonstration projects, increasingly with a sustainable design focus, provide blueprints for informing building briefs and design work. Post-occupancy evaluation results that are published as case studies are a way of advancing sustainable design however confidentiality is 
an issue and revealing faults in buildings is not regarded as good publicity for the designers and building owners. Architects often refer to exemplary buildings to develop a solution set for sustainable buildings. The danger of modelling strategies on a building that has not had POE carried out is that mistakes can be repeated.

\section{Conclusion}

The study supports the proposal that a new framework can help inform a move towards a typology of sustainable building design that in turn can help practitioners develop and refine their approaches to sustainability. The building case studies and detailed examples described in this paper demonstrate identifiable elements within the framework as sustainable principles, the environmental brief, parameters, environmental strategies, blueprints, tools and techniques and evaluation systems. The Design Process Matrix (Table 3) shows these elements mapped onto the traditional RIBA outline plan of work.

The practice group revealed common approaches through their principles, processes and design work. Passive design as a primary approach to reducing energy consumption in a building was evident across all the case study buildings. A more integrated process is also viewed by as vital to the process. The design processes described in the case studies show architects, environmental engineers, prefabrication sub-contractors and other specialists engaged in a collaborative process. The result is a common grouping of strategies for sustainable building design. There are overlaps or general themes in the principles that underpin the strategies as indicated in Table 1. The principles can be more than a useful checklist and can define a sustainable philosophy for a practice. Having a defined set of sustainable principles in place is a valuable tool and some of the practice group have developed sets of their own. The barriers in practice appear to be knowledge and evidence. Architects and engineers require a more comprehensive knowledge of legislation, new technology, materials and environmental design to engage in the integrated design process. Sharing results of the POE of sustainable buildings is one way of promoting best practice and learning lessons in order to avoid repetition of mistakes. The blueprints for future designs should be based on real evidence that original design intents have been met. The building occupants are often the best judges of buildings and provide valuable feedback in addition to any energy monitoring undertaken.

The research group of practices studied are committed to sustainable building design of architectural quality. Currently the focus is on zero carbon, delivering reduced running costs, reducing water and waste and specifying sustainable materials. In future, other aspects of sustainability may be given more coverage; the impact of materials on the health of occupants, for example. There is some evidence that a wider holistic view of sustainability is gaining ground, with the One Planet principles offering a template for developments. Moving sustainability into the mainstream is still, however, a significant challenge ahead. For architectural practices to move forwards, the authors argue that the starting point is the definition of a philosophy and the establishment of a set of guiding principles reflected within a typology of sustainable building design. While the sample group was small it is clear that all are already transforming their approach to sustainable building design. The methodology of the study could be developed to allow practices to further develop a philosophy and refine principles. A Principles / Practice Matrix is being developed as a method of evaluating a practice's approach against well documented sustainable design philosophies that have practical application. This self-reflective approach would take the form of facilitated structured 
conversations among key stakeholders focussed on identifying various systematic classifications of sustainable design principles that can clarify issues at various stages of the process, and the alignment of these with the design philosophy of the practice involved.

\section{References}

CLEGG, P., ET AL. 2007. The Environmental Handbook, London, Rightangle Publishing.

DESAI, P. 2010. One Planet Communities, Chichester, John Wiley \& Sons Ltd.

European Union (EU) European Union Energy Performance of Buildings Directive (Office Journal of the European Union, January 2003)

GRIERSON, D. 2009. Towards Sustainable Building Design, Design Principles and Practices: An International Journal, Volume 3, Number 3, 2009, ISSN 1833-1874.

HOCKERTON HOUSING PROJECT. 2010. Hockerton Housing project [Online]. Available: http://www.hockertonhousingproject.org.uk/SEFS/ID.765/SEFE/ViewItem.asp [Accessed 30th Aug 2010 ].

HYDE, R., WATSON, S., CHESIRE, W., THOMSON, M. 2007. The Environmental Brief, Pathways for Green Design Oxon, Taylor \& Francis, p77-91

International Organisations for Standardization, ISO 14001, 1996

JENCKS, C., KROPF, K. (ed.) 1997. Theories and Manifestoes of contemporary architecture Chichester: Wiley-Academy.

KWOK, A. G., GRONDZIK, W.T. 2007. The Green Studio Handbook, Environmental Strategies for Schematic Design Oxford, Architectural Press.

MOULTRIE, C. 2010. Architectural Design Principles and Processes for Sustainability Unpublished Masters of Research Dissertation, University of Strathcyde Glasgow

RIBA 2007. Outline Plan of Work 2007. London: RIBA.

ROAF, S., CHRICHTON, D., NICOL, F. 2004. Adapting buildings and cities for climate change: a 21 st century survival guide, Oxford, Architectural Press.

SASSI, P. 2006. Strategies for Sustainable Architecture Oxford, Taylor \& Francis

SULLIVAN, I. R. C. B. L. 2007. A Low Carbon Building Standards Strategy for Scotland (The Sullivan Report). Available: http://www.scotland.gov.uk/Resource/Doc/217736/0092637.pdf[Accessed 27th Aug 2010].

VALE, R., VALE, B. 1975. The Autonomous House: design and planning for self-sufficiency, London, Thames \& Hudson Ltd.

VALE, R., VALE, B. 1991. Green Architecture: Design for a Sustainable Future London, Thames and Hudson Ltd, p70-186

VAN DER RYN, S., COWAN, S. 1996. Ecological Design, Washington DC, Island Press.

WORLD COMMISSION ON ENVIRONMENT AND DEVELOPMENT. (WCED) 1987. Our common future. Oxford.

\section{About the Authors}

\section{Dr. David Grierson}

Dr. Grierson is both an architect and academic. He currently directs the Postgraduate Programme in Sustainable Engineering, at Strathclyde University and is a Director of the David Livingstone Centre for Sustainability. His teaching and research interests are in sustainable architecture and urban design. He is particularly active in the integration of teaching and learning activity across the postgraduate community, and the promotion of knowledge exchange and CPD through increased engagement with business, industry, the professions, 
and other institutions. Dr. Grierson is a Fellow of the Higher Education Academy (FHEA) and a visiting lecturer in sustainability at Manchester Metropolitan University, the University of Rome, and the University of Florence. His own architectural work has been exhibited at the Royal Academy Exhibition in London and he has gained a number of architectural awards including two Glasgow Institute of Architecture (GIA) Design Awards and a Sir Rowan Anderson Silver Medal for Architectural Design (RIAS). He has an active role in both the architectural and engineering professions, being listed on the UK Register of Architects (ARB), acting as the Royal Academy of Engineering Visiting Professor (Engineering Design for Sustainable Development) contact for Faculty, and representing the University as a member of the Glasgow Urban Design Panel which advises Glasgow City Council's Planning Committee on planning decisions.

\section{Carolyn Moultrie}

Carolyn Moultrie is a chartered architect with over 20 years of experience across a variety of sectors and more recently has specialised in public sector buildings in particular custodial and healthcare. Carol studied at the Mackintosh School of Architecture, Glasgow School of Art and since then has worked for a variety of private practices in Scotland. She has designed and managed projects in London, Belfast and Glasgow. To widen her knowledge of sustainability in relation to the built environment, Carolyn has recently undertaken a Research Masters (MRes) Building Design and Management for Sustainability at Strathclyde University. For her dissertation, Carolyn chose to look at how architectural practices are transforming design processes to move towards a typology of sustainable design. 


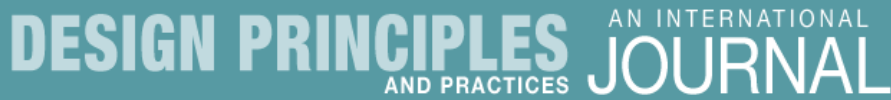

\section{Editor}

Bill Cope, University of Illinois, Urbana-Champaign, USA.

\section{Editorial Advisory Board}

Genevieve Bell - Intel Corporation, Santa Clara, USA.

Michael Biggs - University of Hertfordshire, Hertfordshire, UK.

Thomas Binder - Royal Danish Academy of Fine Arts, Copenhagen, Denmark.

Jeanette Blomberg - IBM Almaden Research Center, San Jose, USA.

Eva Brandt - Danmark Designskole, Copenhagen, Denmark.

Peter Burrows - RMIT University, Melbourne, Australia.

Monika Büscher - Lancaster University, Lancaster, UK.

Patrick Dillon - Exeter University, Exeter, UK.

Michael Gibson - University of North Texas, Denton, USA.

Mary Kalantzis - University of Illinois, Urbana-Champaign, USA.

Loredana Di Lucchio - Sapienza Universita di Roma, Rome, Italy.

Judith Gregory - IIT Institute of Design, Chicago, USA; University of Oslo, Norway.

Clive Holtham - City of London University, London, UK.

Lorenzo Imbesi, Carleton University, Ottawa, Canada.

Hiroshi Ishii - MIT Media Lab, Cambridge, USA.

Gianni Jacucci - University of Trento, Trento, Italy.

Klaus Krippendorff - University of Pennsylvania, Philadelphia, USA.

Terence Love - Curtin University, Perth, Australia.

Bill Lucas - MAYA Fellow, MAYA Design, Inc., Pittsburgh, USA.

Ezio Manzini - Politecnico of Milano, Milan, Italy.

Mario Minichiello - Birmingham Institute of Art and Design, Birmingham, UK.

Julian Orr - Work Practice \& Technology Associates, Pescadero, USA.

Mahendra Patel - Leaf Design, Mumbai, India.

Toni Robertson - University of Technology Sydney, Sydney, Australia.

Terry Rosenberg - Goldsmiths, University of London, London, UK.

Keith Russell - University of Newcastle, Callaghan, Australia.

Liz Sanders - Make Tools, USA.

Maria Cecilia Loschiavo dos Santos - University of São Paulo, São Paulo, Brazil.

Lucy Suchman - Lancaster University, Lancaster, UK.

Ina Wagner - Technical University of Vienna, Vienna, Austria.

Please visit the Journal website at http://www.Design-Journal.com for further information about the Journal or to subscribe. 


\section{The Design Principles \& Practices Community}

This knowledge community is brought together by a shared interest in the process of design and their conceptual foundations. The community interacts through an innovative, annual face-to-face conference, as well as year-round virtual relationships in a weblog, peer reviewed journal and book imprint - exploring the affordances of the new digital media. Members of this knowledge community include academics, designers, administrators, educators, consultants and research students.

\section{Conference}

Members of the Design Community meet at the International Conference on Design Principles and Practices, held annually in different locations around the world. The Design Conference was held at Imperial College London, in 2007; in conjunction with the University of Miami, Florida, USA in 2008; at Technical University Berlin, Germany in 2009; at the University of Illinois at Chicago, USA in 2010; and at Sapienza University of Rome, Italy in 2011. In 2012, the conference will be held at the University of California, Los Angeles, USA.

Our community members and first time attendees come from all corners of the globe. Intellectually, our interests span the breadth of the field of design. The Conference is a site of critical reflection, both by leaders in the field and emerging scholars and practitioners. Those unable to attend the Conference may opt for virtual participation in which community members can either submit a video and/or slide presentation with voice-over, or simply submit a paper for peer review and possible publication in the Journal.

Online presentations can be viewed on YouTube.

\section{Publishing}

The Design Community enables members of its community to publish through three media. First, by participating in the Design Conference, community members can enter a world of journal publication unlike the traditional academic publishing forums - a result of the responsive, non-hierarchical and constructive nature of the peer review process. Design Principles and Practices: An International Journal provides a framework for double-blind peer review, enabling authors to publish into an academic journal of the highest standard.

The second publication medium is through the book series On Design, publishing cutting edge books in print and electronic formats. Publication proposals and manuscript submissions are welcome.

The third major publishing medium is our news blog, constantly publishing short news updates from the Design Community, as well as major developments in the field of design. You can also join this conversation at Facebook and Twitter or subscribe to our email Newsletter. 


\section{Common Ground Publishing Journals}

\begin{tabular}{|c|c|}
\hline $\begin{array}{l}\text { AGING } \\
\text { Aging and Society: An Interdisciplinary Journal } \\
\text { Website: http://AgingAndSociety.com/journal/ }\end{array}$ & $\begin{array}{c}\text { ARTS } \\
\text { The International Journal of the Arts in Society. } \\
\text { Website: www.Arts-Journal.com }\end{array}$ \\
\hline $\begin{array}{c}\text { BOOK } \\
\text { The International Journal of the Book } \\
\text { Website: www.Book-Journal.com }\end{array}$ & $\begin{array}{c}\text { CLIMATE CHANGE } \\
\text { The International Journal of Climate Change: } \\
\text { Impacts and Responses } \\
\text { Website: www.Climate-Journal.com }\end{array}$ \\
\hline $\begin{array}{c}\text { CONSTRUCTED ENVIRONMENT } \\
\text { The International Journal of the } \\
\text { Constructed Environment } \\
\text { Website: www.ConstructedEnvironment.com/journal }\end{array}$ & $\begin{array}{c}\text { DESIGN } \\
\text { Design Principles and Practices: } \\
\text { An International Journal } \\
\text { Website: www.Design-Journal.com }\end{array}$ \\
\hline $\begin{array}{c}\text { DIVERSITY } \\
\text { The International Journal of Diversity in } \\
\text { Organizations, Communities and Nations } \\
\text { Website: www.Diversity-Journal.com }\end{array}$ & $\begin{array}{l}\text { FOOD } \\
\text { Food Studies: An Interdisciplinary Journal } \\
\text { Website: http://Food-Studies.com/journal/ }\end{array}$ \\
\hline $\begin{array}{c}\text { GLOBAL STUDIES } \\
\text { The Global Studies Journal } \\
\text { Website: www.GlobalStudiesJournal.com }\end{array}$ & $\begin{array}{c}\text { HEALTH } \\
\text { The International Journal of Health, } \\
\text { Wellness and Society } \\
\text { Website: www.HealthandSociety.com/journal }\end{array}$ \\
\hline $\begin{array}{c}\text { HUMANITIES } \\
\text { The International Journal of the Humanities } \\
\text { Website: www.Humanities-Journal.com }\end{array}$ & $\begin{array}{c}\text { IMAGE } \\
\text { The International Journal of the Image } \\
\text { Website: www.Onthelmage.com/journal }\end{array}$ \\
\hline $\begin{array}{l}\text { LEARNING } \\
\text { The International Journal of Learning. } \\
\text { Website: www.Learning-Journal.com }\end{array}$ & $\begin{array}{c}\text { MANAGEMENT } \\
\text { The International Journal of Knowledge, } \\
\text { Culture and Change Management. } \\
\text { Website: www.Management-Journal.com }\end{array}$ \\
\hline $\begin{array}{c}\text { MUSEUM } \\
\text { The International Journal of the Inclusive Museum } \\
\text { Website: www.Museum-Journal.com }\end{array}$ & $\begin{array}{c}\text { RELIGION AND SPIRITUALITY } \\
\text { The International Journal of Religion and } \\
\text { Spirituality in Society } \\
\text { Website: www.Religion-Journal.com }\end{array}$ \\
\hline $\begin{array}{c}\text { SCIENCE IN SOCIETY } \\
\text { The International Journal of Science in Society } \\
\text { Website: www.ScienceinSocietyJournal.com }\end{array}$ & $\begin{array}{c}\text { SOCIAL SCIENCES } \\
\text { The International Journal of Interdisciplinary } \\
\text { Social Sciences } \\
\text { Website: www.SocialSciences-Journal.com }\end{array}$ \\
\hline $\begin{array}{c}\text { SPACES AND FLOWS } \\
\text { Spaces and Flows: An International Journal of } \\
\text { Urban and ExtraUrban Studies } \\
\text { Website: www.SpacesJournal.com }\end{array}$ & $\begin{array}{c}\text { SPORT AND SOCIETY } \\
\text { The International Journal of Sport and Society } \\
\text { Website: www.sportandsociety.com/journal }\end{array}$ \\
\hline $\begin{array}{c}\text { SUSTAINABILITY } \\
\text { The International Journal of Environmental, Cultural, } \\
\text { Economic and Social Sustainability } \\
\text { Website: www.Sustainability-Journal.com }\end{array}$ & $\begin{array}{c}\text { TECHNOLOGY } \\
\text { The International Journal of Technology, } \\
\text { Knowledge and Society } \\
\text { Website: www.Technology-Journal.com }\end{array}$ \\
\hline $\begin{array}{c}\text { UBIQUITOUS LEARNING } \\
\text { Ubiquitous Learning: An International Journal } \\
\text { Website: www.ubi-learn.com/journal/ }\end{array}$ & $\begin{array}{l}\text { UNIVERSITIES } \\
\text { Journal of the World Universities Forum } \\
\text { Website: www.Universities-Journal.com }\end{array}$ \\
\hline
\end{tabular}

